\title{
CLUSTER ION CONCENTRATION IN VEHICLE EXHAUST GASES
}

\author{
Andris Skromulis \\ Rezekne Academy of Technologies, Latvia \\ andris.skromulis@rta.lv
}

\begin{abstract}
Evaluation of air quality involves both chemical and physical parameters, however, the importance of the physical ones is often undervalued. A specific integral parameter of the physical state of ambient air is the air ion concentration. Air pollution correlates with air ion concentration. Cluster ions and aerosol ions have the most significant impact on human health. Negative cluster ions are considered to be necessary for human well-being. Previous studies in Rezekne city (Latvia) have highlighted the decrease of positive and especially negative air ion concentrations near the most polluted areas, i.e. the main street junctions and the railway station. Air pollution in Rezekne mainly comes from automotive transport. The aim of this study is to determine the concentration of cluster ions emitted directly from the automobile exhaust pipe. Firstly, the air ion concentration near busy traffic was measured. Secondly, the experiment was carried out using two motor vehicles running on three different types of fuel: gasoline, liquified petroleum gas, and diesel. The portable bipolar light ion counter Sapfir-3M was used in the experiments. The results show that the concentration of air ions in direct exhaust gases can be up to ten times higher than the ambient background concentration. In most cases the experiment revealed the predominance of positive ions over the negative ones, and only in some cases the situation was opposite. It was concluded that only the later chemical and physical processes can lead to decrease of air ion concentration due to pollution. In the article several related circumstances are discussed and proposals on further research are defined.
\end{abstract}

Keywords: cluster ions, air pollution, exhaust gases.

\section{Introduction}

The term air ion in atmospheric physics is generally understood as all particles in the air which are electrically charged and ensure electrical conductivity of the air [1;2]. Air ions are often divided into small or light, medium and large or heavy air ions. Nowadays, the classification of air ions is more based on their physical structure: cluster ions, which diameter is up to $1.6 \mathrm{~nm}$ and mobility below $0.5 \mathrm{~cm}^{2} \cdot \mathrm{V}^{-1} \cdot \mathrm{s}^{-1}$ and aerosol ions, which diameter is larger and mobility lower. Cluster ions consist only of ionized and polarized gas molecules that form clusters, while aerosol ions are also formed by atmospheric aerosols as the nuclei of ion condensation [3]. Air ions in the atmosphere are mainly created by ionizing radiation and they disappear due to mutual recombination of ions with opposite charge marks or when ions settle on surfaces or on larger aerosol particles.

The impact of air ions on wildlife and human health has been studied since the 1940ies. Positive effects are attributed to cluster ions, while heavier ions can also cause damage, because they contain aerosols of various substances, which, due to the charge, can become even more dangerous $[4 ; 5]$. Negative air ions also have bactericidal properties, e.g. [6; 7]. Therapy with negative cluster ions improves people's breathing, heart rate, concentration and overall well-being [8-10]. In some countries, such as Russia and Belarus, the concentration of positive and negative air ions in enclosed areas is regulated by law [11]. From this point of view, it is important to control the concentration of air ions and the unipolarity coefficient and to ensure that the concentration of positive ions is not higher than the concentration of the negative ones, since it is considered that negative ions have beneficial effects on human body.

$$
K=\frac{n^{+}}{n^{-}},
$$

where $K$ - unipolarity coefficient;

$n^{+}-$concentration of positive cluster ions per $1 \mathrm{~cm}^{3}$;

$n$-concentration of negative cluster ions per $1 \mathrm{~cm}^{3}$.

The study of air ion concentrations in various parts of Rezekne showed that the unipolarity coefficient $K$ often exceeds 1 at sites with higher pollution, i.e. industrial zones and street intersections with intense traffic $[12 ; 13]$. Microscopic analysis of the dust collected at these sites showed the presence of soot particles, e.g. at a busy intersection and near a railway junction [14]. A study of the concentration of air ions in different places in Latvia and Finland also revealed that the value of the 
coefficient $K$ outside populated areas is typically less than 1 , while in urban territories it is usually higher than 1 [15]. Thus, it can be concluded that exhaust emissions from road transport affect the concentration of air ions in urban air and that there is a need to investigate the source of these effects in more detail.

The purpose of this article is to find how car exhaust gases affect the concentration of air ions, which ions are emitted from the tailpipe, and whether it is influenced by the type of fuel that is used to power the car. Nowadays, diesel powered cars are becoming more popular in Latvia. As of January $2020,65.5 \%$ of passenger cars in Latvia were equipped with diesel engines and only $34 \%$ with petrol engines.

In Latvia, only $6.63 \%$ of passenger cars are equipped with liquefied petroleum gas equipment. Electric vehicles, on the other hand, still do not constitute even $1 \%$ of the total number of cars (statistics provided by the Road Traffic Safety Directorate) [16], therefore, the problems related to engine exhaust emissions in Latvia are topical.

\section{Materials and methods}

To measure the concentration of air ions, a portable bipolar air ion counter Sapfir-3M was used in all the experiments described. It performed simultaneous measurements of positive and negative air ion concentrations with a minimum resolution of ten ions per $1 \mathrm{~cm}^{3}$. The mobility of detectable air ions was $k \geq 0.4 \mathrm{~cm}^{2} \cdot \mathrm{V}^{-1} \cdot \mathrm{s}^{-1}$. This mobility interval approximately corresponds to the class of cluster ions. During the measurements, the air flow through the aspiration chamber was $230 \pm 23 \mathrm{l} \cdot \mathrm{m}^{-1}$ and the aspiration chamber has a capacity of $13 \pm 1 \mathrm{pF}$. Automatic calibration and zero drift checks were performed before each measurement session [17].

In order to determine the concentration of air ions closer to the pollution source, measurements were made in Rezekne, at the intersection of Latgale and Dārzu streets that have high traffic intensity. Measurements were made three times a day: 8 - 9 a.m., 1 - 2 p.m. and 5 - 6 p.m. Air ion mean values of 16 seconds were recorded for all measurement periods. The measuring device was placed on a wooden base approximately $60 \mathrm{~cm}$ above the ground. At the same time, the number of vehicles crossing the intersections, the ambient air temperature and relative air humidity were also recorded.

In order to find out the charge and concentration of air ions emitted by vehicles in general, measurements of car exhaust gas were also performed, regardless of the type of fuel. For the Experiment 1 a car Ford Escort with a 1.4-liter petrol engine was used. The air ion counter Sapfir-3M was placed on the ground, on a wooden pallet, at a distance of $8 \mathrm{~cm}$ from the tailpipe, perpendicularly to the flow of the exhaust gas, so as to optimally allow the exhaust gas to enter the counter. At the beginning of the experiment, the background concentration was measured for ten minutes, then the engine was started at idle speed for 10 minutes at $1000 \mathrm{rpm}$. For the last ten minutes of the experiment, the engine was turned off and the background concentration of light air ions was measured again. The experiment was carried out in a remote rural area, far from roads and industrial emission sources, so the effect of anthropogenic emissions on background concentrations can be excluded. Such measurements were repeated two times, and then additional measurements were made with the engine running at different speeds. The ambient air temperature was $16-17^{\circ} \mathrm{C}$, relative humidity $65-75 \%$.

To find out the possible difference in air ion emissions of cars with different fuel types, Experiment 2 was conducted. Light air ions in exhaust gases were measured in cars using petrol, liquefied petroleum gas or diesel as fuel. For this purpose, a VW Passat (1.8 1), which runs on both petrol and LPG, and a Renault Espace (2.1 1), which runs on diesel, were used. For each fuel type the mean light air ion values of 16 seconds were recorded for at least five minutes. The experiment was repeated three times, changing the fuel types in different order. The background concentrations of light air ions before and after the experiment were recorded, too. The temperature of the exhaust gas was also measured at the same time. The experiment was performed in Rezekne, in an empty parking area with minimal possible effect on air ion background concentrations. The ambient air temperature was $15{ }^{\circ} \mathrm{C}$, relative humidity $70 \%$. All the cars involved in the experiments ran without catalysator. 


\section{Results and discussion}

\section{Impact of exhaust gases on air ions under intense traffic conditions}

During the experiment, due to street repairs in the city, there was a permanent traffic jam at the intersection of Latgale and Dārzu streets, which increased the accumulation of exhaust gas in the area. The results of the measurements are summarized in the following Table 1.

No significant dependence of the number of vehicles on the time of day was found. In this case, it did not have city-specific traffic volume fluctuations with pronounced morning and evening peaks. At noon the transport intensity did not decrease significantly, but in the evening it increased slightly. These circumstances suggest that during the daylight hours, when there was an active transport movement, there was an approximately constant amount of exhaust gas accumulating in the area surrounding the intersection.

Table 1

Mean values of air ion concentration, traffic intensity and meteorological conditions

\begin{tabular}{|c|c|c|c|c|c|c|c|}
\hline $\begin{array}{c}\text { Measurement } \\
\text { time }\end{array}$ & $\begin{array}{c}\text { Negative } \\
\text { ions, } \mathbf{~ c m}^{-3}\end{array}$ & $\begin{array}{c}\text { Positive } \\
\text { ions, } \mathbf{~ c m}^{-3}\end{array}$ & $\begin{array}{c}\text { Total } \\
\text { ions, } \mathbf{c m}^{-3}\end{array}$ & $\mathbf{K}$ & $\begin{array}{c}\text { Number of } \\
\text { vehicles }\end{array}$ & t, ${ }^{\mathbf{o}}$ & W, \% \\
\hline Morning & 202 & 150 & 352 & 0.74 & 1145 & 2 & 58 \\
\hline Noon & 196 & 343 & 539 & 1.75 & 1127 & 6 & 41 \\
\hline Evening & 117 & 206 & 323 & 1.77 & 1265 & 8 & 26 \\
\hline
\end{tabular}

The total air ion concentration in the evening, irrespective of the charge type, is approximately comparable to the total level in the morning, but the unipolarity coefficient has increased significantly, because the concentration of negative air ions has decreased sharply to $58 \%$ of the morning concentration and the positive ion concentration has increased by $37 \%$. At noon, compared to morning measurements, the total concentration of air ions has increased by $53 \%$, and the concentration of positive ions has increased by $129 \%$, while the concentration of negative ions has slightly decreased. This means that the increase in the total ionization level is mainly due to the increase of positive ions.

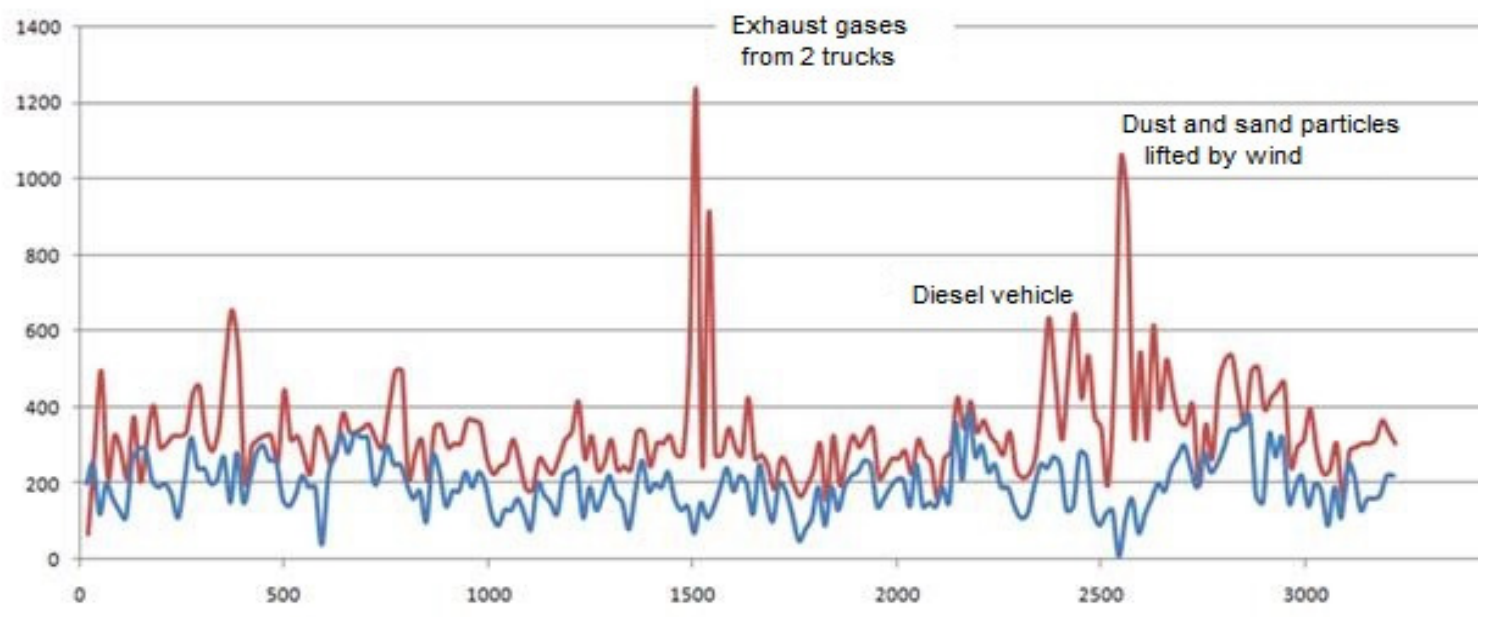

Fig. 1. Air ion concentration at an intersection with intense traffic, noon measurements:

Abscissa - time after beginning the measurement, $\mathrm{s}$; ordinate - air ion concentration, $\mathrm{cm}^{-3}$

Let us look at some sharp but transient peaks of positive ion concentration in Fig. 1 of noon measurements. A rapid peak of concentration was observed, for example, when two trucks stopped at the intersection and emitted diesel engine exhaust gas with soot particles near the air ion counter. A similar, but less pronounced peak was also observed near a diesel car. Many gasoline vehicles with internal combustion engine also periodically stopped near the measuring device, but they did not create any pronounced peaks in ion concentrations. Peaks of positive air ion concentrations in the presence of diesel engine exhaust gas are probably related to the fact that these engines have higher opacity than gasoline engines, especially when the engines are worn out and are not in good technical condition. Diesel exhaust gases are known to contain various aerosols, partially unburned hydrocarbon 
particles and some specific chemicals in elevated concentrations. Temporary peaks can sometimes be also caused by external factors, such as sudden wind gusts, which mix air layers and bring in fine aerosol particles, dust or even fine sand particles. It should be noted that the aforementioned peak concentrations of positive air ions caused by exhaust gas are simultaneously associated with minimum concentrations of negative air ions, which, in other situations, is not always typical for all peak concentrations of positive air ions.

Apparently, in real-world urban conditions, there is no direct correlation between instantaneous air ion concentration and vehicle emissions. An important factor is the time when the pollution is accumulating, as well as complex chemical reactions not only in the gaseous phase, but also in the solid and liquid phase of the polluting aerosols. Unhealthy air ion concentrations are usually a secondary effect of these chemical-physical transformations [18]. The concentration and type of air ions can significantly vary with the distance from emission source, e.g. busy roads [19].

\section{Air ions in exhaust gases of different internal combustion engines}

The data from Experiment 1 were analysed by dividing the entire set of measurements into three series: engine off, engine on, and engine off again. The significance of the difference of arithmetic means was then examined using the Fisher criterion in each two series. Such processing of data obtained in Experiment 1 showed a quite pronounced difference in ion concentration between the time when the engine was turned off and the time when it was turned on, but there was no significant difference between the beginning and the end of the eexperiment when the engine was turned off again. This was the case for both positive and negative ions (Fig.2).

When the Experiment 1 was repeated, it showed significant differences in arithmetic means of the sets in situation when the engine was off at the beginning of the experiment and when it was running at $1000 \mathrm{rpm}$. A significant difference of arithmetic means when the engine was on and when it was stopped again was limited to positive ions; it is was no longer relevant in the area of negative ions. The repetition of Experiment 1 also showed a significant difference of arithmetic means in both cases when the engine was off, i.e. the background air ion concentration after the engine was stopped was significantly different from the concentration before the engine was started (Table 2).

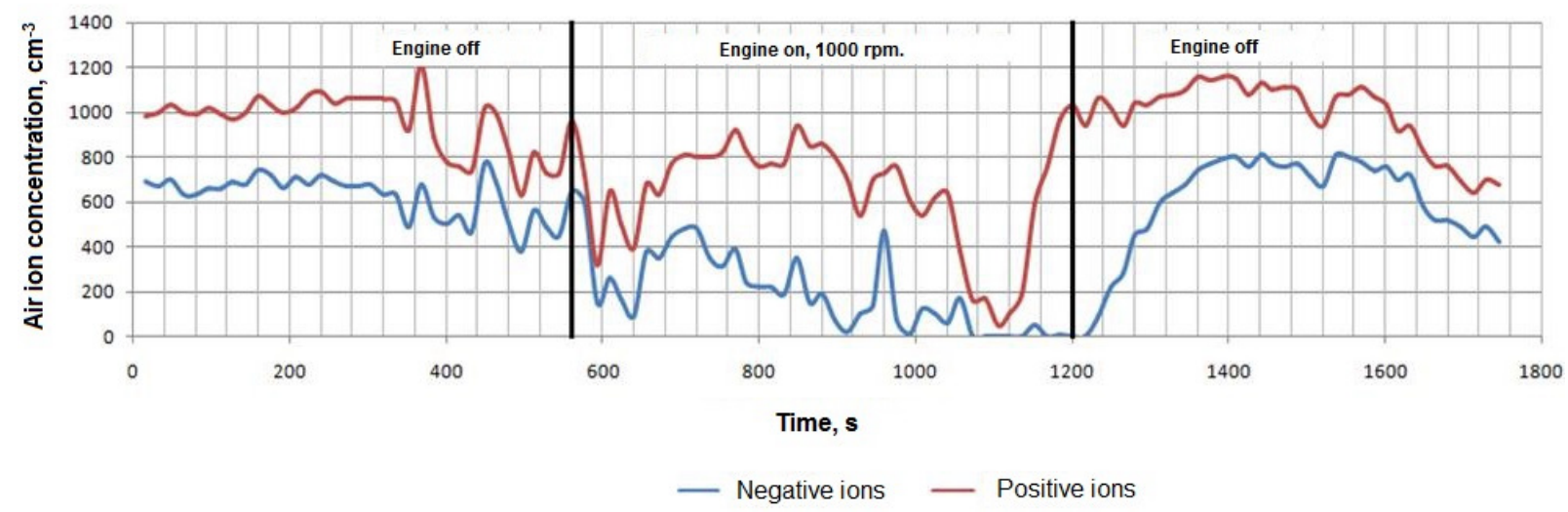

Fig. 2. Measurements of air ion concentrations in vehicle exhaust gas, Experiment 1

The measurements made during the repetition of the Experiment 1, with engine running at various speeds, do not clearly show the differences between the different series (Table 3). Significant differences in arithmetic mean concentrations are only evident in some cases, such as between a turned-off engine and $1000 \mathrm{rpm}$ and between engine operating modes of $1000 \mathrm{rpm}$ and $2000 \mathrm{rpm}$, and only in the area of negative ions. It is possible that the concentration of the air ions emitted and their charge does not significantly depend on the engine operating mode, in this case on the rpm. On the other hand, as the engine speed increases, the speed of the exhaust gas flow from the tailpipe also increases significantly. Without changing the position of the ion counter relative to the tailpipe, a proportionally higher flow may bypass the ion counter and mix with the ambient air at a greater distance from the vehicle. As a result, there is a larger number of emitted air ions that cannot be caught by the measuring device. 
Although the difference in arithmetic means of air ion concentrations between different data series is not always significant, different engine operating modes are almost always associated with transient fluctuations in air ion concentration. Speaking about starting the engine, Experiment 1 showed a decrease in the concentration of ions of both polarities, but the repetition of the experiment demonstrated an increase, mainly in the area of positive air ions, so in both cases there was an obvious change. The reason for the completely opposite tendencies of changes in the concentration of air ions after starting the engine in two seemingly identical attempts may be the varying degrees of engine warm-up. At the beginning of Experiment 1, the engine was warmed up to the allowable operating temperature above $40{ }^{\circ} \mathrm{C}$, whereas during the repetition of the experiment it reached its maximum operating temperature above $90{ }^{\circ} \mathrm{C}$ at which the cooler automatically starts. The decrease in the concentration of air ions of both polarities during engine operation can be explained by the increased concentration of unburned hydrocarbon aerosols (including soot) in the exhaust gas. During Experiment 1, after stopping the engine air ion concentrations rapidly reached their previous levels, but, during the repetition of the experiment, there was no dramatic change in air ion concentrations after engine stopping, however significant differences between the levels of both background concentrations occurred. This suggests that in this case the engine exhaust gas has had a longer lasting effect on the air ion concentration in the ambient air.

Table 2

Results of Experiment 1 and its repetition

\begin{tabular}{|c|c|c|c|c|c|c|c|c|}
\hline \multirow[b]{2}{*}{ rpm } & \multicolumn{4}{|c|}{ Experiment 1} & \multicolumn{4}{|c|}{ Repetition of Experiment 1} \\
\hline & $\begin{array}{l}\text { Negative } \\
\text { ions, } \mathrm{cm}^{-3}\end{array}$ & $\begin{array}{l}\text { Positive } \\
\text { ions, } \mathbf{c m}^{-3}\end{array}$ & $\begin{array}{c}\text { Total } \\
\text { ions, } \mathrm{cm}^{-3}\end{array}$ & $\mathbf{K}$ & $\begin{array}{c}\text { Negative } \\
\text { ions, } \mathbf{c m}^{-3} \mathbf{n}^{-}\end{array}$ & $\begin{array}{l}\text { Positive } \\
\text { ions, } \mathrm{cm}^{-3}\end{array}$ & $\begin{array}{c}\text { Total ions, } \\
\mathrm{cm}^{-3}\end{array}$ & $\mathbf{K}$ \\
\hline 0 & 626 & 961 & 1587 & 1.5 & 348 & 633 & 981 & 1.8 \\
\hline 1000 & 201 & 639 & 840 & 3.2 & 406 & 701 & 1107 & 1.7 \\
\hline 0 & 587 & 990 & 1577 & 1.7 & 390 & 593 & 983 & 1.5 \\
\hline
\end{tabular}

Concentration of air ions, engine running at various rpm

Table 3

\begin{tabular}{|c|c|c|c|c|c|}
\hline Stage & rpm & Negative ions, $\mathbf{~ c m}^{-\mathbf{3}}$ & Positive ions, $\mathbf{~ m}^{\mathbf{3}}$ & Total ions, $\mathbf{~ m}^{-3}$ & $\mathbf{K}$ \\
\hline 1 & 0 & 411 & 513 & 924 & 1.2 \\
\hline 2 & 1000 & 481 & 585 & 1065 & 1.2 \\
\hline 3 & 2000 & 322 & 498 & 820 & 1.5 \\
\hline 4 & 1000 & 351 & 534 & 885 & 1.5 \\
\hline 5 & 3000 & 334 & 512 & 847 & 1.5 \\
\hline 6 & 1000 & 230 & 470 & 700 & 2.0 \\
\hline 7 & 0 & 335 & 512 & 847 & 1.5 \\
\hline
\end{tabular}

In almost all cases, at least a short-term increase in air ion concentration is observed when the engine is started or its speed is increased, but as the engine operating mode stabilizes, the air ion concentration stabilizes too. When the engine operating modes change, as is the case when the engine is started or its speed is increased, the engine briefly runs in non-optimal mode and the fuel mixture is richer than is normally required in stationary mode. Typically, such changes of engine operating modes are also related to incomplete combustion of the fuel mixture resulting in elevated concentrations of $\mathrm{CO}$ and unburned hydrocarbons in the exhaust gas. It can be seen that transient fluctuations in the concentrations of pollutants in the exhaust gas also result in transient fluctuations in the concentration of air ions. Unfortunately, rapid changes in engine operating modes cannot be avoided in city traffic.

Exhaust gases from the combustion of LPG are frequently considered to be ecologically cleaner than those from petrol and diesel [20]. LPG-fueled internal combustion engines have showed the highest concentration of negative air ions in the exhaust gas, with the unipolarity coefficient $K=1.19$ being the lowest of all fuels (Table 4). The highest proportion of positive air ions was found in the exhaust gas of the diesel engine, $K=1.52$. The cars used in the experiment were not equipped 
with a catalyst or soot filter, so the exhaust gas was not purified in any way. The relatively high concentration of positive air ions in the exhaust gas is thought to be related to the presence of soot particles, which presence is most expressed in the diesel exhaust gas, and the least expressed in LPG combustion products. The content of negative air ions can be explained by the water vapour emitted by the burning of hydrocarbons. For example, the concentration of negative air ions in hot air vapour can range from 2000 to 2500 ions per $\mathrm{cm}^{3}$, whereas the concentration of positive air ions is usually below 2000. The engine operating temperature during the experiment was $90{ }^{\circ} \mathrm{C}$ for petrol and gas engines and $80^{\circ} \mathrm{C}$ for diesel engines.

Average concentration of air ions in the exhaust gas of different fuels

\begin{tabular}{|c|c|c|c|c|c|}
\hline Parameter & $\begin{array}{c}\text { Background at } \\
\text { the beginning }\end{array}$ & LPG & Petrol & Diesel & $\begin{array}{c}\text { Background at } \\
\text { the end }\end{array}$ \\
\hline Negative ions, $\mathrm{cm}^{-3}$ & 610 & 1262 & 910 & 1073 & 395 \\
\hline Positive ions, $\mathrm{cm}^{-3}$ & 355 & 1508 & 1120 & 1630 & 351 \\
\hline $\mathrm{K}$ & 0.58 & 1.19 & 1.23 & 1.52 & 0.89 \\
\hline
\end{tabular}

It is possible that the harmful effects of exhaust gases and the predominance of positive ions over the negative ones are most pronounced in the range of heavier air ions, as, for example, most of the soot particles are usually positively charged and correspond to the class of heavy air ions. The attention should rather be paid to the change in background concentrations of light air ions in the area where the experiment was conducted. From the data obtained it can be seen that after the experiment in which the car engine was running on different fuels for about an hour, the concentration of negative cluster ions in the area decreased drastically, whereas the concentration of positive air ions almost did not change. Thus, the value of the unipolarity coefficient $K$ approached 1 . The result of the experiment shows that some time is needed for the heavier charged particles to react with the light negative air ions and to reduce their total concentration, thus making the ambient air less favourable to human health.

However, it must be acknowledged that the results obtained by measuring the concentration of cluster ions in various exhaust gases require further discussion and investigation of the problem. In an attempt to repeat the above mentioned measurements, no significant differences were observed in air ion concentration depending on the type of fuel. Car engines were warmed to normal operating temperature, but it was impossible to find similar ambient conditions with an average air temperature of $7^{\circ} \mathrm{C}$ and a relative humidity of approximately $95 \%$. As exhaust gases mix with the ambient air, this may be a significant factor influencing the measurement results. The relative humidity of the air is also the maximum at which Sapfir-3M can be used.

\section{Conclusions}

Atmospheric pollution caused by transport affects the concentration of air ions in urban environment, generally reducing the concentration of mainly negative cluster ions, which increases the unipolarity coefficient $K$ from about 0.7 to 1.7. The experiments described in this article prove that the vehicle exhaust gases are an additional source of positive cluster ions, as it is well illustrated in some cases. However, the car engine emits both positive and negative cluster ions in relatively large quantities, typically above 1000 ions per $\mathrm{cm}^{-3}$ and there is a wide range of concentration fluctuations. Of the most common types of internal combustion engine fuels, the lowest $K$ value in the experiment was found for liquefied petroleum gas $(K=1.19)$, whereas the diesel had $K=1.52$ and petrol $K=1.23$. In addition, the petrol car demonstrated a lower total emission of cluster ions than gas and diesel engines. This circumstance, as well as the significant fluctuations of the concentration, point to the large influence of side effects in the experiments. In order to better and more clearly investigate this problem, in future experiments it is necessary to make measurements prior to the mixing of the exhaust gas with atmospheric air and to measure the full range of air ions, not just cluster ions, while analyzing the chemical composition of the exhaust gas and the water vapor concentration in it. The experiments show that exhaust gases have a long-term effect on air quality. In almost all cases, the total concentration of cluster ions decreased after the experiment and the prevalence of positive air ions over the negative ones increased. 


\section{References}

[1] Dolezalek H., Reiter R., Kröling P. Basic comments on the physics, occurrence in the atmosphere, and possible biological effects of air ions. Int. J. Biometeorol., No. 29, 1985, pp. 207-242.

[2] Tammet H. Air ions. CRC Handbook of Chemistry and Physics, 79th edition, No. 14, 1998, pp. 32-34.

[3] Hõrrak U., Salm J., Tammet H. Statistical characterization of air ion mobility spectra at Tahkuse Observatory: classification of air ions. J. Geophys. Res. Atmos., No. 105, 2000, pp. 9291-9302.

[4] Mc Clellan R. O., Miller F. J. An overview of EPA's proposed revision of the particulate matter standard. CIIT Activities (Chemical Industry Institute of Toxicology), No. 17, 1997, pp. 1-23.

[5] Skromulis A. Impact of Cluster Ions and Air Pollution on Human Health. Proceedings of the 12th International Scientific and Practical Conference "Environment. Technology. Resources", Volume I, 2019, pp. 267-271.

[6] Shepherd S. J., Beggs C. B., Smith C. F., Kerr K. G., Noakes C. J., Sleigh P. A. Effect of negative air ions on the potential for bacterial contamination of plastic medical equipment. BMC Infect Dis. Apr 12;10:92, 2010. DOI: 10.1186/1471-2334-10-92.

[7] Kim Y. S., Yoon K. Y., Park J. H., Hwang J. Application of air ions for bacterial de-colonization in air filters contaminated by aerosolized bacteria. Science of the Total Environment, Vol. 409, Issue 4, 2011, pp. 748-755.

[8] Varga A. Forschungsbericht über die physiologische Wirkung von Luftionen und deren Bedeutung als Umweltfaktoren (Research report on the physiological effects of air ions and their importance as environmental factors), Heidelberg: Elektro Bioklimatische Forschungsstelle des Hygiene - Instituts des Universität Heidelberg. 1972. 28 p. (In German).

[9] Varga A. Biologische Wirkung von Luftionen (Biological effects of air ions), Heidelberg: Verlag für Medizin Dr.E.Fischer, 1986. 100p. (In German).

[10] Fornof K. T., Gilbert G. O. Stress and physiological, behavioral and performance patterns of children under varied air ion levels, Int J. Biometeorol, No. 32, 1988, pp. 260-270.

[11] СанПиН 2.2.4.1294-03 Гигиенические требования к аэроионному составу воздуха производственных и общественных помещений, (Hygienic requirements for aeroionic composition of air in industrial and public buildings), Moscow: Федеральный центр Госсанэпиднадзора Минздрава России, 2003. 11 p. (In Russian).

[12] Skromulis A., Noviks G. Atmospheric Light Air Ion Concentrations and Related Meteorologic Factors in Rezekne City, Latvia. In: Journal of Environmental Biology, No. 4, 2012.

[13] Skromulis A., Matisovs I., Noviks G. Complex Evaluation of Air Quality in Rezekne. Proceedings of the 8th International Scientific and Practical Conference " Environment. Technology. Resources". Volume 1. RHEI, Rezekne, 2011, pp. 160-168.

[14] Noviks G., Skromulis A. Gaisa vides kvalitātes monitoringa pilnveidošanas iespēju analīze (Analysis of air environment quality monitoring improvement possibilities). Proceedings of the 7th International Scientific and Practical Conference "Environment. Technology. Resources". Volume 1. RHEI, Rezekne, 2009, pp. 273-283. (In Latvian).

[15] Skromulis A., Noviks G. Comparison of Air Ionization Levels in Different Ecosystems. In: Journal of International Scientific Publications "Ecology \& Safety", Volume 5, Part 1. Info Invest, Bulgaria, 2011, pp. 21-31.

[16]CSDD statistics: Registrēto transportlīdzekḷu sadalījums pēc degvielas veida (Breakdown of registered vehicles by fuel type). (In Latvian). [online] [29.03.2020]. Available at: https://www.csdd.lv/transportlidzekli/registreto-transportlidzeklu-skait .

[17]Счётчик аэроионов „Сапфир-3м” Руководство по эксплуатации (Counter of air ions "Sapphire-3m” Operation manual), Kazan: НПФ „ЯНТАРЬ”, 2008. 16 p. (In Russian).

[18] Yu F., Turco R. From molecular clusters to nanoparticles: The role of ambient ionization in tropospheric aerosol formation. Journal of Geophysical Research, No. 106, 2001, pp. 4797-4814.

[19] Jayaratne R., Ling Xu., Morawska L. Observation of ions and particles near busy roads using a Neutral Cluster and Air Ion Spectrometer (NAIS). Atmospheric Environment, 84(1), 2014, pp. 198-203.

[20] Ryskamp R. Emissions and Performance of Liquefied Petroleum Gas as a Transportation Fuel: A Review. West Virginia University Center for Alternative Fuels, Engines, and Emissions. 2017. 26 p. [online] [11.02.2020] Available at: https://auto-gas.net/wp-content/uploads/2019/11/2017WLPGA-Literature-Review.pdf 